\title{
Primary metabolism components of seeds from Brazilian Amazon tree species
}

\author{
José Francisco de C. Gonçalves ${ }^{1 *}$, Andreia V. Fernandes ${ }^{1}$, Antonio Fernando M. Oliveira ${ }^{2}$, \\ Lílian F. Rodrigues ${ }^{1}$ and Ricardo A. Marenco ${ }^{1}$ \\ ${ }^{1}$ Instituto Nacional de Pesquisa da Amazônia, C.P. 478, CEP 69011-970, Manaus, AM, Brasil; ${ }^{2}$ Universidade Bandeirantes; \\ * Corresponding author:jfc@inpa.gov.br \\ Received: 22/01/2002, Accepted: 12/08/2002
}

The contents of the main components of the primary metabolism (soluble sugars, starch, proteins, oils, fatty acids) and minerals ( $\mathrm{P}, \mathrm{Ca}, \mathrm{Mg}, \mathrm{K}, \mathrm{Fe}, \mathrm{Zn}, \mathrm{Mn}, \mathrm{Cu}$ ) were characterized in seeds of five Brazilian Amazon tree species (Andira parviflora, Bertholletia excelsa, Helicostylis tomentosa, Hymenaea parviflora, and Parkia pendula). Soluble sugar contents were high in P. pendula seeds (14\%), whereas starch predominated in A. parviflora seeds (58.7\%). A. parviflora and $H$. parviflora seeds were rich in proteins (35.1\% and $32.4 \%$, respectively). The oil contents ranged from $1.4 \%$ in A. parviflora to $70.7 \%$ in B. excelsa. Only B. excelsa and P. pendula seeds may be considered oilseeds, with $70.7 \%$ and $28.4 \%$ oil, respectively. The fatty acid compositions showed high proportions of unsaturated fatty acids, mainly oleic and linoleic acids, regardless of the species. B. excelsa and P. pendula also showed high amounts of $\mathrm{P}, \mathrm{Mg}, \mathrm{K}$ and $\mathrm{Zn}$.

Key words: Fatty acids, minerals, oils, proteins, soluble sugars, starch.

Componentes do metabolismo primário de sementes de espécies arbóreas da Amazônia brasileira: Os conteúdos dos principais componentes do metabolismo primário (açúcares solúveis, amido, proteínas, óleos, ácidos graxos) e de minerais $(\mathrm{P}, \mathrm{Ca}, \mathrm{Mg}, \mathrm{K}, \mathrm{Fe}, \mathrm{Zn}, \mathrm{Mn}, \mathrm{Cu})$ foram caracterizados em sementes de cinco espécies arbóreas da Amazônia Brasileira (A. parviflora, B. excelsa, H. tomentosa, H. parviflora e P. pendula). O conteúdo de açúcares solúveis foi maior em P. pendula (14\%) e o de amido predominou em sementes de A. parviflora (58,7\%). Sementes de A. parviflora (35.1\%) e H. parviflora (32.4\%) mostraram-se ricas em proteínas. O conteúdo de óleo variou de 1,4 \% em A. parviflora a 70,7 \% em B. excelsa. Sementes de P. pendula têm $28,4 \%$ de óleo e junto com sementes de $B$. excelsa, podem ser consideradas como sementes oleaginosas. Independente da espécie, a composição de ácidos graxos mostrou maior proporção de ácidos graxos insaturados, principalmente ácidos oléico e linoléico. B. excelsa e P. pendula também apresentaram maiores quantidades de $\mathrm{P}, \mathrm{Mg}, \mathrm{K}$ e $\mathrm{Zn}$.

Palavras-chave: Ácidos graxos, açúcares solúveis, amido, minerais, óleos, proteínas.

Scientific information about the chemical compositions of tropical seeds may be important both conceptually, to understand the physiological process of seeds, and technically by providing more information for agro industry. They may also have an ecological significance, as a nutrient source for would-be predators and pathogens. Other studies have shown that some seeds could be used industrially as raw materials for paint formulation, based on the amounts and nature of their oils (Eromosele et al., 1998). Therefore, economic use depends partly on the quantitative and qualitative aspects of their organic reserves, especially carbohydrates, proteins and lipids. This communication studies the organic and mineral composition of seeds from five Amazonian tree species.

Fruits of five Amazonian species (Andira parviflora / Leguminosae; Bertholletia excelsa / Lecythidaceae; Helicostylis tomentosa / Moraceae; Hymenaea parviflora / Leguminosae; Parkia pendula / Leguminosae) were randomly harvested from trees near Manaus (Amazonas, 
Brazil) from November 2000 to July 2001 and processed to obtain their seeds. Seed sample sizes were determined according to the procedure recommended by the International Seed Testing Association (ISTA, 1998). Seed reserve tissues were extracted from tegument-free seeds at the INPA Laboratory, dried $\left(70^{\circ} \mathrm{C}, 48 \mathrm{~h}\right)$, ground and then preserved at $-20{ }^{\circ} \mathrm{C}$ until processing. Soluble sugars and starch were extracted with ethanol $95 \%(\mathrm{v} / \mathrm{v})$ and $30 \%(\mathrm{v} / \mathrm{v})$ perchloric acid, respectively (Passos, 1996a). Both components were quantified by the phenol sulphuric acid method (Dubois et al., 1956) using glucose (Sigma) as a standard. Oil was extracted in a Soxhlet apparatus with petroleum ether $\left(40\right.$ to $\left.60^{\circ} \mathrm{C}\right)$ for $24 \mathrm{~h}$ and concentrated in a rotary evaporator under gaseous nitrogen to remove the solvent. The extracted oil was determined and the seed oil contents expressed on a dry weight basis (AOAC, 1990). Oil samples of each species were hydrolyzed with a $10 \%$ methanol $\mathrm{KOH}(\mathrm{p} / \mathrm{v})$ solution. They were then converted to their respective methyl-esters using diazomethane and identified by gas chromatography (HP 5890 S-II Plus) and mass spectrometry (HP 5989B). A capillary column of silica
HP-5MS (30 m x $0.25 \mathrm{~mm}$ ) and helium as a carrier gas with a constant flux of $1.2 \mathrm{~cm}^{3} \cdot \mathrm{min}^{-1}$ were used. The initial temperature was $160{ }^{\circ} \mathrm{C} \cdot \mathrm{min}^{-1}$, increasing by $3{ }^{\circ} \mathrm{C} \cdot \mathrm{min}^{-1}$ until $250^{\circ} \mathrm{C}$. Injector and detector temperatures were 250 ${ }^{\circ} \mathrm{C}$ and $280{ }^{\circ} \mathrm{C}$, respectively. Fatty acids were identified by comparison with standard fatty acid methyl esters (Sigma Chemical) and also compared with a mass spectrum of the wiley 275 - pc library (Hewlett Packard). Seeds were ground with pestle and mortar, and extracted in $80 \%$ ethanol (20 ml. $\mathrm{g}^{-1}$ dry seeds, 10 min until boiling) (Passos, 1996b). The pellet recovered after centrifugation $\left(10,000 g_{\mathrm{n}}, 20^{\circ} \mathrm{C}\right.$ during $\left.10 \mathrm{~min}\right)$ was extracted with 0.1 $\mathrm{M} \mathrm{NaOH}$ and after a new centrugation, proteins were assayed in the supernatant according to Bradford (1976), using bovine serum albumin (Sigma) as standard. Samples of storage tissue were digested with concentrated nitric and perchloric acid $(1: 1 \mathrm{v} / \mathrm{v})$. Total $\mathrm{P}$ was determined calorimetrically by the molybdenum blue method (Murphy and Riley, 1965), and $\mathrm{Ca}^{2+}, \mathrm{Mg}^{2+}, \mathrm{K}^{+}, \mathrm{Fe}^{2+}, \mathrm{Zn}^{2+}$ and $\mathrm{Cu}^{2+}$ were determined using an atomic absorption spectrophotometer (Perkin-Elmer/1100B, Germany). The results were submitted to analyses of variance and means were compared by the Tukey test $(\mathrm{p}<0.05)$.

Table 1. Chemical composition of seeds from five Amazonian tropical species

\begin{tabular}{lrrrrr}
\hline Component $^{\mathrm{a}}$ & A. parviflora & B. excelsa & $\begin{array}{c}\text { H. tomentosa } \\
\text { (grams per 100g of dry weight) }\end{array}$ & H. parviflora & P. pendula \\
\hline Soluble sugar & $3.99 \pm 0.05 \mathrm{~b}$ & $3.58 \pm 0.28 \mathrm{~b}$ & $4.19 \pm 0.32 \mathrm{~b}$ & $1.17 \pm 0.04 \mathrm{c}$ & $13.97 \pm 0.77 \mathrm{a}$ \\
Starch & $58.70 \pm 2.09 \mathrm{a}$ & $4.42 \pm 0.17 \mathrm{~d}$ & $16.35 \pm 0.21 \mathrm{c}$ & $23.44 \pm 1.89 \mathrm{~b}$ & $22.05 \pm 0.93 \mathrm{~b}$ \\
Protein & $35.08 \pm 4.72 \mathrm{a}$ & $15.69 \pm 0.80 \mathrm{~b}$ & $10.38 \pm 1.95 \mathrm{~b}$ & $32.37 \pm 2.80 \mathrm{a}$ & $12.90 \pm 2.14 \mathrm{~b}$ \\
Oil & $1.43 \pm 0.06 \mathrm{e}$ & $70.66 \pm 2.92 \mathrm{a}$ & $12.78 \pm 1.18 \mathrm{c}$ & $8.16 \pm 0.94 \mathrm{~d}$ & $28.45 \pm 0.34 \mathrm{~b}$ \\
\hline
\end{tabular}

${ }^{a}$ Means \pm standard deviation of four replicates. Mean values followed by the same letters do not differ significantly by the Tukey test $(p<0.05)$.

P. pendula seeds presented the highest soluble sugar contents (14\%), with nearly 3.5 times as much soluble sugar than A. parviflora, B. excelsa and H. tomentosa seeds and 11.9 times more than $H$. parviflora seeds (table 1 ), whereas starch predominated in A. parviflora seeds (58.7\%). A. parviflora and H. parviflora seeds presented the highest protein contents (35.1 and $32.4 \%$, respectively), whereas $B$. excelsa, $H$. tomentosa and $P$. pendula seeds had protein contents ranging from 10.4 to $13.7 \%$. Oil contents of the five species ranged from 1.4 $\%$ to $70.7 \%$. However, only $B$. excelsa and P. pendula may be considered oilseeds, with $70.7 \%$ and $28.4 \%$, respectively. Among the species included in this study, only $B$. excelsa seeds have been largely investigated. The high oil $(70.7 \%)$ and protein $(15.7 \%)$ contents of $B$. excelsa seeds are in agreement with previous reports (Adams, 1975; FAO, 1986). On the other hand, B. excelsa seeds presented intermediary soluble sugar $(3.6 \%)$ and starch (4.4\%) contents. According to Wolff and Kwolek (1971), low carbohydrate contents are expected in oilrich seeds. The protein contents in A. parviflora and $H$. parviflora seeds are similar to those observed in soybeans, peanuts and other legume crops, making such species good sources of protein. According to Carbonaro et al. 
(2000), plant seeds represent a major source of dietary proteins, with amounts varying from $10 \%$ (dry mass) in cereals to around $40 \%$ in certain legumes and oilseeds. The oil content observed in P. pendula seeds (28.4\%) was three times greater than values reported by Lago et al. (1987) for two other Parkia species which also occur in the Brazilian Amazon. When compared to the oil content of African species, P. pendula was similar to that observed by Gunstone et al. (1972) for P. roxburghii (20 $\%$ oil). In this study, the H. parviflora oil content ( $8.2 \%)$ was twice as high as the values observed for the same species in Singapore (Cornelius et al., 1970). Unsaturated fatty acids predominated over saturated acids (table 2), with high contents being observed in B. excelsa, A. parviflora and P. pendula seeds (75.2 and $74.2 \%$ and $71.1 \%$, respectively). Palmitic acid $\left(\mathrm{C}_{16: 0}\right)$ was the main saturated fatty acid identified, whereas oleic $\left(\mathrm{C}_{18: 1}\right)$ and linoleic $\left(\mathrm{C}_{18: 2}\right)$ were the most representative unsaturated fatty acids. Large amounts of unsaturated fatty acids have been observed in many species from the Brazilian Amazon (Lago et al., 1987). In this study, P. pendula seeds contained approximately $71.1 \%$ of unsaturated fatty acids, $61.2 \%$ of which correspond to linoleic acid (table 2). However, in two African Parkia species, P. biglobosa and $P$. bicolor, the predominance of saturated over unsaturated fatty acids was of nearly $90 \%$ (Aiyelaagbe et al., 1996). Fatty acid compositions of the Amazonian species (table 2), especially those of the $\mathrm{C}_{18}$ series, agree with previous results (Adams, 1975). The most abundant one was linoleic acid, representing 39.8, 47.3 and
$61.2 \%$ of the fatty acid composition of $H$. parviflora, $H$. tomentosa and $P$. pendula, respectively. Linoleic acid contents of $B$. excelsa and $H$. parviflora, however, are slightly lower than those previously reported (Assunção et al., 1984; Lago et al. 1987). Fatty acid composition of the Parkia seeds is in agreement with the results of Lago et al. (1987). Similar amounts of oleic and linoleic acid were found in $B$. excelsa, where they represented $75 \%$ of the dry mass of seeds. It is worth noting that oleic acid was the major fatty acid in A. parviflora. Few long-chain fatty acids $(>18 \mathrm{C})$ were found in all species. Arachidic acid $\left(\mathrm{C}_{20: 0}\right)$ was found in $A$. parviflora, B. excelsa and $P$. pendula, whereas behenic acid $\left(\mathrm{C}_{22: 0}\right)$ and lignoceric $\left(\mathrm{C}_{24: 0}\right)$ were not found in B. excelsa (table 2$)$. This is the first time that arachidic acid is reported in $B$. excelsa native to the Amazon. It is possible that the production of fatty acids is limited to their biosynthesis of up to 18 carbons. Arachidic and behenic acids appear to accumulate in several species of the Parkia genus (Lago et al., 1987; Aiyelaagbe et al., 1996). B. excelsa storage tissue had significantly greater $\mathrm{P}, \mathrm{Mg}$ and $\mathrm{Zn}$ contents than A. parviflora and H. parviflora storage tissues (table 3), whereas $P$. pendula had significantly more $\mathrm{K}$ and $\mathrm{Cu}$ than A. parviflora, B. excelsa and H. parviflora. Only $A$. parviflora and $H$. parviflora presented low mineral contents. For B. excelsa, our results are similar to those reported by (Adams, 1975). However, no references were found regarding the mineral contents of the other four species.

Table 2. Fatty acid composition (\%) of seeds from five Amazonian tropical species

\begin{tabular}{lccccc}
\hline Fatty acids $^{\mathrm{a}}$ & A. parviflora & B. excelsa & H. tomentosa & \multicolumn{1}{c}{ H. parviflora } & P. pendula \\
\hline Palmitic $\left(\mathrm{C}_{16: 0}\right)$ & $8.56 \pm 0.40 \mathrm{~cd}$ & $13.15^{\mathrm{b}} \pm 2.05 \mathrm{~b}$ & $23.57 \pm 2.04 \mathrm{a}$ & $6.39 \pm 0.47 \mathrm{~d}$ & $10.70 \pm 0.89 \mathrm{bc}$ \\
Stearic $\left(\mathrm{C}_{18: 0}\right)$ & $11.17 \pm 0.25 \mathrm{~b}$ & $10.36 \pm 1.22 \mathrm{~b}$ & $6.41 \pm 0.79 \mathrm{c}$ & $18.18 \pm 0.86 \mathrm{a}$ & $8.98 \pm 0.85 \mathrm{~b}$ \\
Oleic $\left(\mathrm{C}_{18: 1}\right)$ & $49.08 \pm 1.54 \mathrm{a}$ & $37.42 \pm 1.23 \mathrm{~b}$ & $13.80 \pm 0.29 \mathrm{c}$ & $16.86 \pm 0.99 \mathrm{c}$ & $9.90 \pm 1.27 \mathrm{~d}$ \\
Linoleic $\left(\mathrm{C}_{18: 2}\right)$ & $25.17 \pm 1.87 \mathrm{~d}$ & $37.75 \pm 1.05 \mathrm{c}$ & $47.34 \pm 2.04 \mathrm{~b}$ & $39.80 \pm 0.94 \mathrm{c}$ & $61.21 \pm 1.89 \mathrm{a}$ \\
Arachidic $\left(\mathrm{C}_{20: 0}\right)$ & $2.20 \pm 0.70 \mathrm{~b}$ & $1.32 \pm 0.38 \mathrm{~b}$ & - & - & $3.93 \pm 0.32 \mathrm{a}$ \\
Behenic $\left(\mathrm{C}_{22: 0}\right)$ & $2.21 \pm 0.67 \mathrm{c}$ & - & $5.28 \pm 0.34 \mathrm{~b}$ & $8.91 \pm 0.46 \mathrm{a}$ & $3.46 \pm 0.74 \mathrm{c}$ \\
Lignoceric $\left(\mathrm{C}_{24: 0}\right)$ & $1.61 \pm 0.64 \mathrm{c}$ & - & $3.60 \pm 0.65 \mathrm{~b}$ & $9.86 \pm 0.31 \mathrm{a}$ & $1.82 \pm 0.43 \mathrm{c}$ \\
Total unsaturated & 74.25 & 75.17 & 61.14 & 36.66 & 43.34 \\
Total saturated & 25.75 & 24.83 & 38.86 & 28.89
\end{tabular}

${ }^{a}$ Means \pm standard deviation of four replicates. Mean values followed by the same letters do not differ significantly by the Tukey test $(p<0.05)$. 
Table 3. Mineral composition of seeds from five Amazonian tropical species (milligrams per 100g of dry weight)*

\begin{tabular}{lccccc}
\hline Element & A. parviflora & B. excelsa & H. tomentosa & H. parviflora & P. pendula \\
\hline Phosphorus & $74.75 \pm 2.75 \mathrm{~d}$ & $564.50 \pm 10.47 \mathrm{a}$ & $116.50 \pm 8.58 \mathrm{c}$ & $120.50 \pm 2.08 \mathrm{c}$ & $223.25 \pm 5.19 \mathrm{~b}$ \\
Calcium & $99.00 \pm 7.53 \mathrm{c}$ & $206.75 \pm 23.57 \mathrm{~b}$ & $304.00 \pm 5.12 \mathrm{a}$ & $94.75 \pm 5.91 \mathrm{c}$ & $167.25 \pm 13.94 \mathrm{~b}$ \\
Magnesium & $230.75 \pm 15.71 \mathrm{~b}$ & $312.50 \pm 14.34 \mathrm{a}$ & $222.75 \pm 6.29 \mathrm{~b}$ & $182.50 \pm 8.06 \mathrm{~b}$ & $318.75 \pm 21.45 \mathrm{a}$ \\
Potassium & $133.00 \pm 12.52 \mathrm{~cd}$ & $514.75 \pm 16.76 \mathrm{~b}$ & $174.75 \pm 2.82 \mathrm{c}$ & $98.25 \pm 1.71 \mathrm{~d}$ & $655.75 \pm 23.57 \mathrm{a}$ \\
Iron & $10.60 \pm 0.42 \mathrm{~b}$ & $9.67 \pm 0.83 \mathrm{~b}$ & $15.38 \pm .00 \mathrm{a}$ & $9.47 \pm 0.57 \mathrm{~b}$ & $11.25 \pm 0.42 \mathrm{~b}$ \\
Zinc & $3.55 \pm 0.37 \mathrm{~b}$ & $7.10 \pm 0.50 \mathrm{a}$ & $6.12 \pm .40 \mathrm{a}$ & $2.85 \pm 0.32 \mathrm{~b}$ & $6.96 \pm 0.47 \mathrm{a}$ \\
Manganese & $7.32 \pm 0.38 \mathrm{~b}$ & $6.85 \pm 0.34 \mathrm{~b}$ & $14.37 \pm .10 \mathrm{a}$ & $8.70 \pm 0.36 \mathrm{~b}$ & $7.20 \pm 0.45 \mathrm{~b}$ \\
Copper & $1.15 \pm 0.13 \mathrm{~b}$ & $1.17 \pm 0.24 \mathrm{~b}$ & $1.65 \pm .13 \mathrm{ab}$ & $0.95 \pm 0.13 \mathrm{~b}$ & $2.45 \pm 0.31 \mathrm{a}$ \\
\hline
\end{tabular}

* Means \pm standard deviation of four replicates. Mean values followed by the same letters do not differ significantly by the Tukey test $(p<0.05)$.

Acknowledgements: We thank Dr. Isolde D.K. Ferraz and Dr. Débora Yara A.C. Santos for technical assistance. Financial support from MCT-JICA (project N. 309-1064-1).

\section{REFERENCES}

Adams CF (1975) Nutritive value of American foods. Agricultural Research Service, US Dept. Agriculture Handbook, 456.

Aiyelaagbe OO, Ajaiyeoba EO, Ekundayo O (1996) Studies on the seed oils of Parkia biblobosa and Parkia bicolor. Plant Foods Hum. Nutr. 49:229-233.

AOAC (1990) Official Methods of Analysis. 15 th $^{\text {edn }}$. Association of Official Analytical Chemists: Washington, D.C.

Assunção FP, Bentes MHS, Serruya HA (1984) Comparison of the stability of oils from Brazil nuts, Para rubber and passion fruit seeds (Bertholletia excelsa, Hevea brasiliensis, Passiflora edulis). J. Am. Oil Chem. Soc. 61:1031-1036.

Bradford MM (1976) A rapid and sensitive method for the quantification of microgram quantities of protein utilizing the principle of protein-dye binding. Anal. Biochem. 72:248-254.

Carbonaro M, Grant G, Cappelloni M, Pusztai A (2000) The perspectives into factors limiting in vivo digestion of legume proteins: Antinutritional compounds of storage proteins? J. Agric. Food Chem. 48:742-749.

Cornelius JA, Hammonds TW, Leicester JB, Ndabahweji JK, Rosie DA, Shone GG (1970) New tropical seed oils. III - Component acids of Leguminosae and other seed oils. J. Sci. Food Agric. 21:49-50.
Dubois M, Giles KA, Hamilton JK (1956) Colorimetric method for determination of sugars and related substances. Anal. Chem. 28:350-356.

Eromosele IC, Eromosele CO, Innazo P, Njerim P (1998) Studies on Some Seeds and Seed Oils. Biores. Technol. 64:245-247.

FAO (1986) Food and fruit-bearing forest species - 3. Examples from Latin America. FAO Forestry Paper 44/3, (Rome: FAO).

Gunstone FD, Steward SR, Cornelius JA, Hammonds TW (1972) New tropical seed oils. IV - Component acids of Leguminosae and other seed oils including useful. J. Sci. Food Agric. 3:49-60.

ISTA (1998) International rules for seed testing. Seed Sci. Technol. 24:Supplement.

Lago RCA, Pereira DA, Siqueira FAR, Szpiz RR, Oliveira JP (1987) Estudo preliminar das sementes e do óleo de cinco espécies da Amazônia. Acta Amazônica 16/ 17:369-376.

Murphy J, Riley JP (1965) A modified single solution method for estimation of phosphate in natural matters. Anal. Chem. Acta 27:3-36.

Passos LP (1996a) Métodos Analíticos e Laboratoriais em Fisiologia Vegetal. In: Carboidratos - Análise Quantitativa, pp.53-65. EMBRAPA-CNPGL, Coronel Pacheco.

Passos LP (1996b) Métodos Analíticos e Laboratoriais em Fisiologia Vegetal. In: Proteínas - Análise Quantitativa, pp.41-48. EMBRAPA-CNPGL, Coronel Pacheco.

Wolff IA, Kwolek WF (1971) Lipids of the Leguminosae. In: Harbone JB, Boulter D, Turner BL, (eds), Chemotaxonomy of the Leguminosae, pp.231-235. London Academic, London. 